TITLE:

\title{
Fundamental Absorption of Solid Solutions of Alkali Halides Containing $\mathrm{KBr}$ (Abstract_要旨)
}

$\operatorname{AUTHOR}(S)$ :

Murata, Takatoshi

\section{CITATION:}

Murata, Takatoshi. Fundamental Absorption of Solid Solutions of Alkali Halides Containing KBr. 京都大学, 1969, 理学博士

ISSUE DATE:

1969-01-23

URL:

http://hdl.handle.net/2433/213058

RIGHT: 


\section{【57】}

氏名村 田 隆 紀

学位の種類理学 博士

学位記 番号、論 理 博 第 261 号

学位授与の日付昭 和 44 年 1 月 23 日

学位授与の要件 学 位 規則第 5 条第 2 項 該 当

学位論文題目 Fundamental Absorption of Solid Solutions of Alkali

Halides Containing KBr

（臭化カリウムを含むハロゲン化アルカリ混晶の基礎吸収）

論文調査委員教授 中查) 井祥夫 教授富田和久 教授 長谷田泰一郎 教授 浅井健次郎

\section{論文内容 要 旨}

アルカリハライドの基礎吸収については，1930年以来多くの研究がなされているが，特に最近は精密測 定が可能になり，吸収帯の微細構造が明らかにされてきている。他方，理論的にもとれらの物質のエネル ギー帯構造の計算が多くなされ, 電子的構造と光学的吸収構造の関連の研究も盛んになりつつある。固有 吸収帯の低エネルギー端にあらわれる一対の鋭い吸収帯は，八ロゲンイオンの励起による励起子としてよ く理解されているが，それより高エネルギー側の構造は未だその成因が明らかでない。中です $\mathrm{KBr}$ は励 起子帯の高エネルギー側に明瞭な三重構造を示す第二固有吸収帯を持っているが，その起源は確定してい ない。

本論文は，KBr に打いて，その金属成分であるカリウムイオンを他の陽イオン，即ちルビジゥム又は ナトリウムイオンと一部置換した混晶, 及び八ロゲン成分である臭素イオンを塩素イオンと置換した混晶 をつくり，それぞれの場合について，(1)混晶をつくったととが $\mathrm{KBr}$ の第一励起子帯や第二固有吸収帯 （三重構造をむつ）に及ぼす影響を確かめるてと，(2)その影響の濃度依存性を追求することによって，特 に第二固有吸収帯の成因を探ることをその目的としている。

吸収測定の結果, 陽イオン置換の混晶系 ( $\mathrm{KBr}-\mathrm{RbBr}$ 及び $\mathrm{KBr}-\mathrm{NaBr}$ ) においては，第一励起子带の 形状は全濃度領域にわたって保たれていることがわかった。但し, 吸収帯の変位の仕方は二つの系で大き く異なり, $\mathrm{K}-\mathrm{Rb}$ 系では濃度に対して直線的に変位するが, $\mathrm{K}-\mathrm{Na}$ 系では純物質の吸收帯よりも低エネル ギー側にまで及ぶ変位をすることが観測された。第二固有吸収帯は，K-Rb 系については第一励起子帯と 同様な振舞をするが, $\mathrm{K}-\mathrm{Na}$ 系の場合には混晶中の $\mathrm{NaBr}$ の濃度の増加と共に三重構造が徐々に不明瞭 になり，次第に $\mathrm{NaBr}$ に特有な幅広い単一の吸収帯として見わけがつかなくなるという結果を得た。

これらの測定に際し, 結果の再現性ならびに精度を確かめるため, 申請者は吸収測定に使用した混晶の 薄膜の安定性を検討した。参考論文 1 及び 2 の研究から $\mathrm{K}^{+}$イオンと $\mathrm{Rb}^{+}$イオンが混在する塩は, 安定 な混晶をつくるととが知られている。一方 $\mathrm{K}^{+}$イオンと $\mathrm{Na}^{+}$イオンとは, イオン半径が大きく異なるため 
にそれらのイオンを含む安定な混晶を，空気中でつくるととはできない。そのため， $\mathrm{K}-\mathrm{Rb}$ 系で行なった 粉末試料のX線回折の実験をとの系では行なえないので, 蒸着薄膜について直接電子線回折像を観察し, 格子定数を決定した。その結果, との系に扔いても $\mathrm{K}-\mathrm{Rb}$ 系と同様に混晶の格子定数は濃度と共に一様 に変化し，その值が濃度の関数として一意的に定められるととを見出し，薄膜が安定であるととを確かめ た。

これらの観測結果に基づき，申請者は陽イオン置換の混晶系における第一固有吸収帯のふるまいは，価 電子带，伝導帯共にそれぞれ単一の状態が混晶中で形成されているととの反映であると結論するに至っ た。また， $\mathrm{KBr}-\mathrm{NaBr}$ 系に怙ける吸収帯の低エネルギー側への大きな变位の原因は， $\mathrm{KBr}-\mathrm{NaBr}$ の伝導 帯のエネルギー差の大きいととによると推論した。

$\mathrm{KBr}-\mathrm{KCl}$ 混晶系については以前に Mahr による室温での測定ならびにその解析が試みられているが， 今回の液体窒素温度における測定の結果, 室温の場合の解析はあらためる必要のあるととが判明し, Mahr によってえられた結論とは異なって KBr の第一励起子帯の变位は濃度に対して直線的でないて と, $\mathrm{KBr}$ の第二固有吸収帯の高エネルギー側の成分の強度が， $\mathrm{KBr}$ の濃度の減少とともに増大するとと などの事実を確認した。

以上述べた種々の混晶系における第一励起子帯の振舞は, 混晶の電子的構造と吸収帯の変化についての 最近のモデル計算の結果とも，ほぼ一致するととが，おのおのの場合について確かめられた。

また，第二固有吸収帯についてはおのおのの混晶系の場合の振舞の相異点を比較検討し，さらに，カリ ウム塩である $\mathrm{KCl}$ 及びKIのエネルギー帯構造の計算結果，および，小野寺・豊沢による励起子帯の理論 を参照して，KBr における三重構造の吸収帯の成因は，ブリルアン帯の $\mathrm{X}_{3}$ 状態への带間遷移に伴なう励 起子である, と推論した。

\section{論 交 審 查の結 果の要旨}

この諭文は，臭化カリウムを主体とするアルカリハライドの基礎吸収を詳しく测定し，それより得られ る知見に基づいて，励起子带及び電子構造について各種の考察を試みたものである。申請者は，アルカリ ハライドの固有吸収帯の成因を解明するために，例として $\mathrm{KBr}$ をとりげ，次のような方法を採用した。 即ち $\mathrm{KBr}$ を中心にして，その金属成分を他のアルカリ金属イオン $\left(\mathrm{Na}^{+}\right.$又は $\left.\mathrm{Rb}^{+}\right)$により置換した混 晶, 及びハロゲン成分を他のハロゲンイオン $\left(\mathrm{Cl}^{-}\right)$で置換した混晶につき，その吸収スペクトルの変化 を濃度の関数として, 詳細に追求した。

その結果，まず成分イオンの半径の違いが大きい場合（KBr-NaBr）でも蒸着薄膜状態で安定な混晶を つくっているととを確認した。てれは，吸収測定結果の再現性からも類推できるととではあるが，申請者 は薄膜の電子回折像を直接観测することにより，格子定数の一様な変化を測定して，その検証を行なって いる。

混晶をつくった場合の $\mathrm{KBr}$ のスペクトルの变化は，混入する相手によってその模様の異なるととがわ かったが，それらの違いは，最近試みられた理論的考察に基づいて，矛盾なく説明できることを示してい る。ただし， $\mathrm{KBr}-\mathrm{NaBr}$ 系において，混晶系における吸収帯の位置の変化が，純物質におけるものより低 
エネルギー側にまで及ぶ現象は従来の理論によっても説明できず，将来にわたって物理的に興味のある問 題が提起されている。

ハロゲンを置換した $\mathrm{KBr}-\mathrm{KCl}$ 系については，数年前に Mahrによって室温における測定が試みられ， その結果が従来の理論的考察による予想と一致しない点が，最近問題となっていた。しかしながら今回申 請者によって行なわれた低温における測定の結果, 従来の測定結果は根本的に修正する必要のあることが 明らかになった。

これらの研究結果は,すべて, 混晶内に括ける電子の振舞, およびそれを通じて結晶の電子的構造の特 性を明らかにする上に，多大な貢献をなすものであり，またての問題に対する今後の研究発展の重要な端 緒となるあのと考えられる。参考論文で得られた結果は，すべて主論文にあられた内容を指向する意味で の予備的な内容之意義をもっており，申請者が固体物性の分野，殊に真空紫外領域の光物性の分野に扔い て，広い知識とすぐれた研究能力をもつととを示している。

以上のように, 本論文は独自の方法によって, 励起子の問題をより深く理解する上で, 固体物性の研究 の発展に寄与するとてろが少なくない。従って, 本論文は理学博士の学位論文として価值があるすのと認 められる。 